International Journal of Physical Sciences and Engineering
Available online at www.sciencescholar.us
Vol. 5 No. 1, April 2021, pages: 8-15
ISSN: 2550-6951 E-ISSN: 2550-6943
https://doi.org/10.29332/ijpse.v5n1.800

\title{
Design and Manufacture of Air Quality Measurements Based on Arduino ATmega2560 Using Dust ZH03A Laser Sensor
}

\author{
Crossmark
}

I Made Satriya Wibawa1* ${ }^{*}$ I Ketut Putra²

Manuscript submitted: 27 December 2020, Manuscript revised: 18 January 2020, Accepted for publication: 09 February 2021

*Corresponding Author

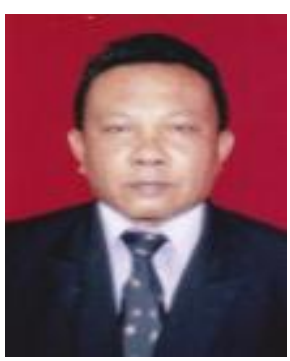

Keywords

Arduino ATmega 2560;

PM1.0

PM2.5;

ZH03A sensor;

\begin{abstract}
This study aims at designing an air quality measuring instrument that is more efficient, relatively cheaper, and can be carried because. It has a smaller shape and size compared to the existing tools in the meteorology, climatology, and geophysics agency (BMKG). The main processor uses the Arduino ATmega 2560 microcontroller. This microcontroller functions as the processor for PM2.5 and PM10 concentrations which are the output of the ZH03A sensor. The design results are calibrated with a standard tool, namely BAM1020 which is owned by the BMKG air quality sector to measure air quality. The calibration results obtained that the average value issued by the reference tool which was used as a standard compared to the ZH03A sensor in the design results for PM 2.5 was $6.5 \mu \mathrm{m} / \mathrm{m} 3$, and for the average value of PM1.0 was $2.8 \mu \mathrm{m} / \mathrm{m} 3$ the calculated air pollution standard index (ISPU) value is $126 \mu \mathrm{m} / \mathrm{m} 3$ including the medium category according to the air pollution standard index.
\end{abstract}

International Journal of Physical Sciences and Engineering (C) 2021. This is an open access article under the CC BY-NC-ND license (https://creativecommons.org/licenses/by-nc-nd/4.0/).

\section{Contents}

Abstract

1 Introduction...

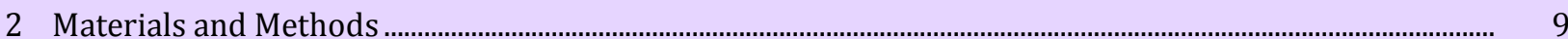

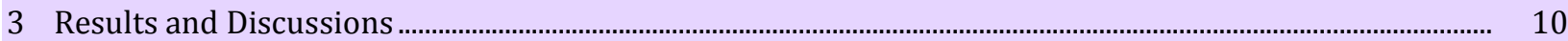

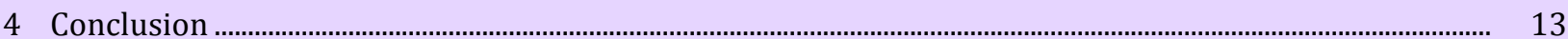

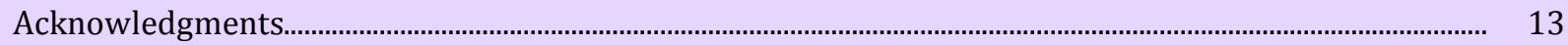

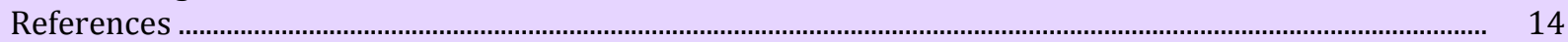

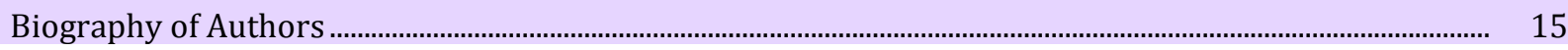

${ }^{1}$ Physics Department, Faculty of Mathematics and Natural Sciences, Udayana University, Indonesia

${ }^{2}$ Physics Department, Faculty of Mathematics and Natural Sciences, Udayana University, Indonesia 


\section{Introduction}

Bali is one of the areas that have the largest tourism destinations in Indonesia, the number of existing tourist destinations has resulted in the high arrival of foreign and domestic tourists which affect the population of this area. The high population increases the number of activities both motorized and industrial which have implications for increased air pollution and decreased air quality.

Particulate Matter (PM) is a type of hazardous pollutant and one of the parameters of air quality pollution in the Republic of Indonesia Government Regulation No. 41 of 1999 (Azhar, 2015). Particulate matter has the most dangerous impact on human health which can cause Acute Respiratory Infections (ARI). Particulate matter that is commonly found in the community is $\mathrm{PM}_{2.5}$ and $\mathrm{PM}_{10}$ which are some of the parameters of air pollution. $\mathrm{PM}_{2.5}$ is a pollutant released from vehicle emissions, which is often referred to as respirable dust because it can penetrate the lung parenchyma, causing a decrease in the vital capacity of the lungs (Falahdina, 2017). $\mathrm{PM}_{10}$ is a particulate size under 10 micrometers that comes from burning land and motor vehicle fumes which have a very dangerous impact on human health because its size is so small that it can reach the deepest part of the lungs and even circulate in the bloodstream (Nazaruddin, 2018).

The tools commonly used to measure air quality are the Beta Attenuation Mass Monitor 1020 (BAM-1020) and the high volume air sampler (HVAS). This tool has a very large size, making it difficult to carry anywhere (lace mobility). These tools are also limited in number and expensive so that not all places are covered by this tool in the laboratory.

We will try to design an air quality measuring instrument based on the Arduino ATmega 2560 with a laser dust sensor ZH03A with a simpler system, smaller size (Ansori, 2017; Budiyono, 2001). It has higher mobility and a much cheaper price. This design tool is expected to be able to automatically detect the level of air quality in public places, especially $\mathrm{PM}_{2.5}$ and $\mathrm{PM}_{10}$ pollutants which are very dangerous to the health of the body. The tool to be designed can provide real-time air quality information and the detection results will be displayed on the LCD (Pham, 2014; Al-Haija et al., 2014).

\section{Materials and Methods}

The design of an air quality measuring instrument based on the Atmega 2560 microcontroller with laser dust sensor ZH03A was carried out at the Electronics and Instrumentation Laboratory of the Physics Study Program, Faculty of Mathematics and Natural Sciences, Udayana University. The overall scheme of the design tool is as Figure 1.

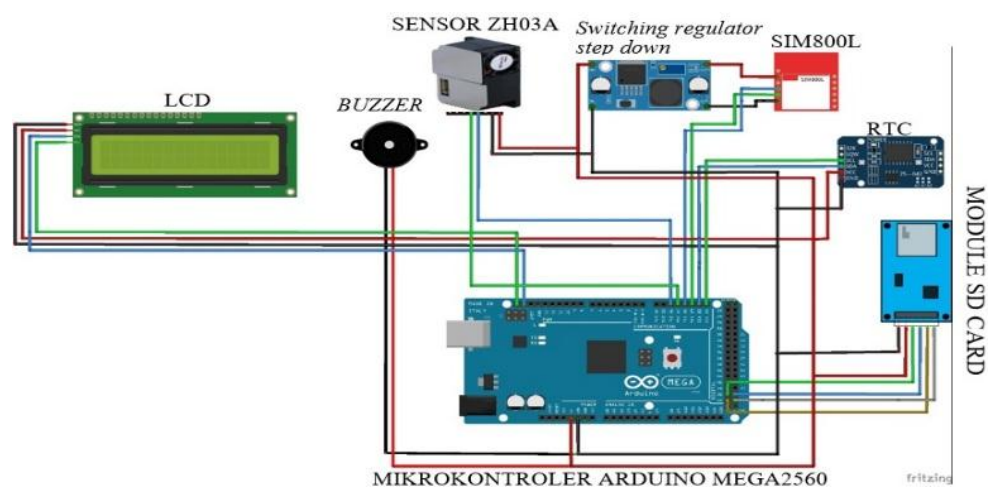

Figure 1. Schematic of the entire network of measurement systems $\mathrm{PM}_{2.5}$ and $\mathrm{PM}_{10}$

The software design uses the $C$ language programming through the Arduino IDE application version 1.8.5. This program will always run when the microcontroller gets a voltage source (Krüger et al., 2011; Berkowicz et al., 1996). Tool design calibration is carried out by comparing it with measuring instruments available in BMKG.

Wibawa, I. M. S., \& Putra, I. K. (2021). Design and manufacture of air quality measurements based on arduino ATmega 2560 using dust ZH03A laser sensor. International Journal of Physical Sciences and Engineering, 5(1), 8-15. https://doi.org/10.29332/ijpse.v5n1.800 


\section{Results and Discussions}

The air quality measuring instrument has been successfully designed with a ZA03A sensor based on the ATmega 2560 microcontroller (Chandra, 2012; Fahruddin, 2014). The calibration of the design tool is carried out by comparing the ZA03A sensor reading results with the operational instrument as a reference owned by the BMKG air quality division. Testing is only carried out on parameters $\mathrm{PM}_{2.5}$ and $\mathrm{PM}_{1.0}$.

Table 1

Results of PM2.5 Parameter Calibration

\begin{tabular}{llllll}
\hline \multirow{2}{*}{ No. } & Date & Time & \multicolumn{3}{c}{ Reading Results } \\
\cline { 4 - 5 } & & & $\begin{array}{l}\text { Reference } \\
\left(\mu \mathrm{m} / \mathrm{m}^{3}\right)\end{array}$ & $\begin{array}{l}\text { ZH03A. } \\
\mathrm{PM}_{25}\left(\mu \mathrm{m} / \mathrm{m}^{3}\right)\end{array}$ & \\
\hline 1 & $10 / 8 / 20$ & $11: 00$ & 102 & 98 & 4 \\
2 & $10 / 8 / 20$ & $12: 00$ & 100 & 102 & -2 \\
3 & $10 / 8 / 20$ & $13: 00$ & 98 & 78 & 20 \\
4 & $10 / 8 / 20$ & $14: 00$ & 87 & 98 & -11 \\
5 & $10 / 8 / 20$ & $15: 00$ & 75 & 67 & 8 \\
6 & $10 / 8 / 20$ & $16: 00$ & 78 & 70 & 8 \\
7 & $10 / 8 / 20$ & $17: 00$ & 67 & 56 & 11 \\
8 & $10 / 8 / 20$ & $18: 00$ & 52 & 58 & -6 \\
9 & $10 / 8 / 20$ & $19: 00$ & 42 & 58 & -16 \\
10 & $10 / 8 / 20$ & $20: 00$ & 36 & 35 & 1 \\
11 & $10 / 8 / 20$ & $21: 00$ & 30 & 40 & -10 \\
12 & $10 / 8 / 20$ & $22: 00$ & 28 & 52 & -24 \\
13 & $10 / 8 / 20$ & $23: 00$ & 28 & 42 & -14 \\
14 & $10 / 8 / 20$ & $24: 00$ & 26 & 42 & -16 \\
15 & $11 / 8 / 20$ & $01: 00$ & 26 & 56 & -30 \\
16 & $11 / 8 / 20$ & $02: 00$ & 30 & 34 & -4 \\
17 & $11 / 8 / 20$ & $03: 00$ & 28 & 38 & -10 \\
18 & $11 / 8 / 20$ & $04: 00$ & 42 & 57 & -15 \\
19 & $11 / 8 / 20$ & $05: 00$ & 60 & 68 & -8 \\
20 & $11 / 8 / 20$ & $06: 00$ & 67 & 78 & -11 \\
21 & $11 / 8 / 20$ & $07: 00$ & 72 & 78 & -6 \\
22 & $11 / 8 / 20$ & $08: 00$ & 89 & 98 & -9 \\
23 & $11 / 8 / 20$ & $09: 00$ & 88 & 98 & -10 \\
24 & $11 / 8 / 20$ & $10: 00$ & 95 & 101 & -6 \\
\hline Average Difference & & & & $-6,5$ \\
\hline
\end{tabular}

In the calibration results above table, it can be seen that the average PM2.5 value issued by the reference tool is used as a standard compared to the ZH03A sensor at the design result is $6.5 \mu \mathrm{m} / \mathrm{m} 3$. 


\section{PM2.5 ZH03A Comparison Chart with Reference}

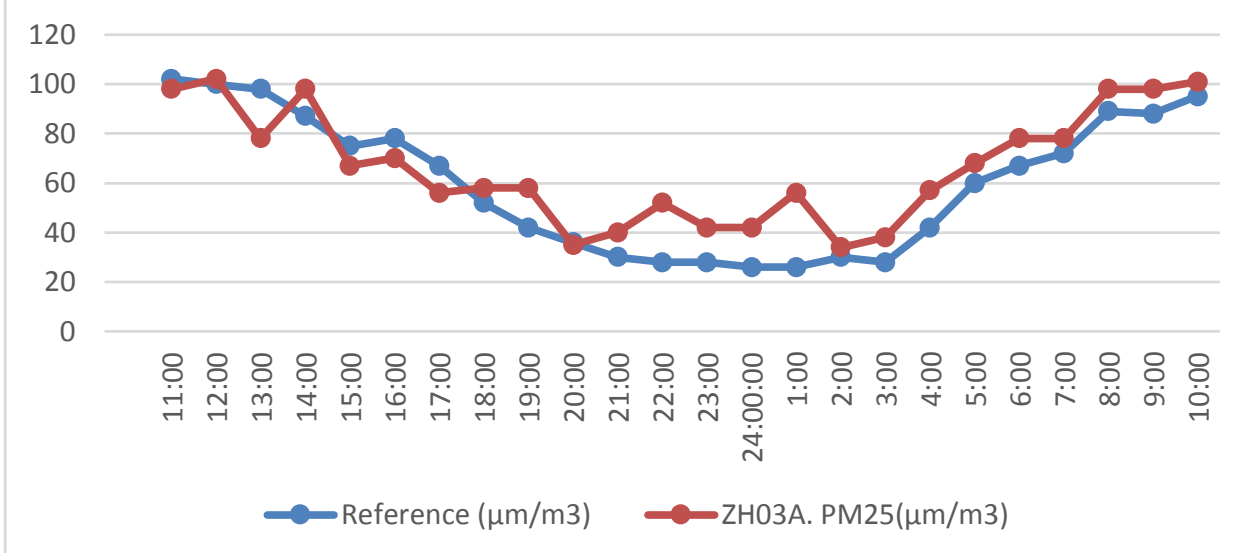

Figure 2. Comparison Graph PM2.5 ZH03A with Reference

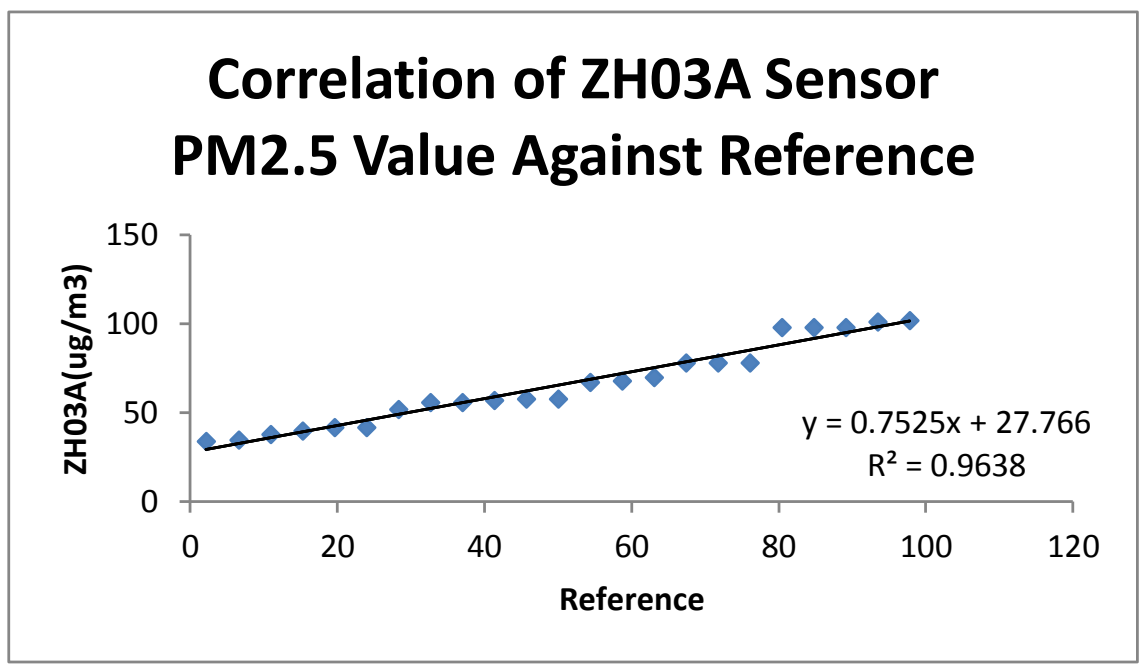

Figure 3. Correlation Graph of PM2.5 Concentration

Table 2

Calibration Results for PM1.0 Parameters

\begin{tabular}{|c|c|c|c|c|c|}
\hline \multirow[b]{2}{*}{ No. } & \multirow[b]{2}{*}{ Date } & \multirow[b]{2}{*}{ Time } & \multicolumn{2}{|c|}{ Reading Results } & \multirow[b]{2}{*}{ Correction } \\
\hline & & & $\begin{array}{l}\text { Reference } \\
\left(\mu \mathrm{m} / \mathrm{m}^{3}\right)\end{array}$ & $\begin{array}{l}\text { ZH03A. PM1.0 } \\
\left(\mu \mathrm{m} / \mathrm{m}^{3}\right)\end{array}$ & \\
\hline 1 & $12 / 8 / 20$ & $11: 00$ & 108 & 102 & 6 \\
\hline 2 & $12 / 8 / 20$ & $12: 00$ & 102 & 98 & 4 \\
\hline 3 & $12 / 8 / 20$ & $13: 00$ & 89 & 96 & -7 \\
\hline 4 & $12 / 8 / 20$ & $14: 00$ & 82 & 87 & -5 \\
\hline 5 & $12 / 8 / 20$ & $15: 00$ & 67 & 75 & -8 \\
\hline 6 & $12 / 8 / 20$ & $16: 00$ & 62 & 78 & -16 \\
\hline
\end{tabular}

Wibawa, I. M. S., \& Putra, I. K. (2021). Design and manufacture of air quality measurements based on arduino ATmega 2560 using dust ZHO3A laser sensor. International Journal of Physical Sciences and Engineering, 5(1), 8-15. https://doi.org/10.29332/ijpse.v5n1.800 


\begin{tabular}{llllll}
\hline 7 & $12 / 8 / 20$ & $17: 00$ & 56 & 67 & -11 \\
8 & $12 / 8 / 20$ & $18: 00$ & 58 & 48 & 10 \\
9 & $12 / 8 / 20$ & $19: 00$ & 52 & 42 & 10 \\
10 & $12 / 8 / 20$ & $20: 00$ & 38 & 36 & 2 \\
11 & $12 / 8 / 20$ & $21: 00$ & 36 & 40 & -4 \\
12 & $12 / 8 / 20$ & $22: 00$ & 30 & 48 & -18 \\
13 & $12 / 8 / 20$ & $23: 00$ & 28 & 42 & -14 \\
14 & $12 / 8 / 20$ & $24: 00$ & 26 & 42 & -16 \\
15 & $13 / 8 / 20$ & $01: 00$ & 26 & 50 & -24 \\
16 & $13 / 8 / 20$ & $02: 00$ & 30 & 34 & -4 \\
17 & $13 / 8 / 20$ & $03: 00$ & 28 & 38 & 8 \\
18 & $13 / 8 / 20$ & $04: 00$ & 42 & 34 & 8 \\
19 & $13 / 8 / 20$ & $05: 00$ & 60 & 52 & 20 \\
20 & $13 / 8 / 20$ & $06: 00$ & 70 & 50 & 12 \\
21 & $13 / 8 / 20$ & $07: 00$ & 80 & 68 & 18 \\
22 & $13 / 8 / 20$ & $08: 00$ & 88 & 70 & -12 \\
23 & $13 / 8 / 20$ & $09: 00$ & 80 & 92 & -16 \\
\hline 2 & $13 / 8 / 20$ & $10: 00$ & 80 & 96 & $-2,8$ \\
\hline
\end{tabular}

In the calibration results table above, it can be seen that the average PM1.0 value issued by the reference tool which is used as the standard compared to the ZH03A sensor in the design results is $2.8 \mu \mathrm{m} / \mathrm{m} 3$.

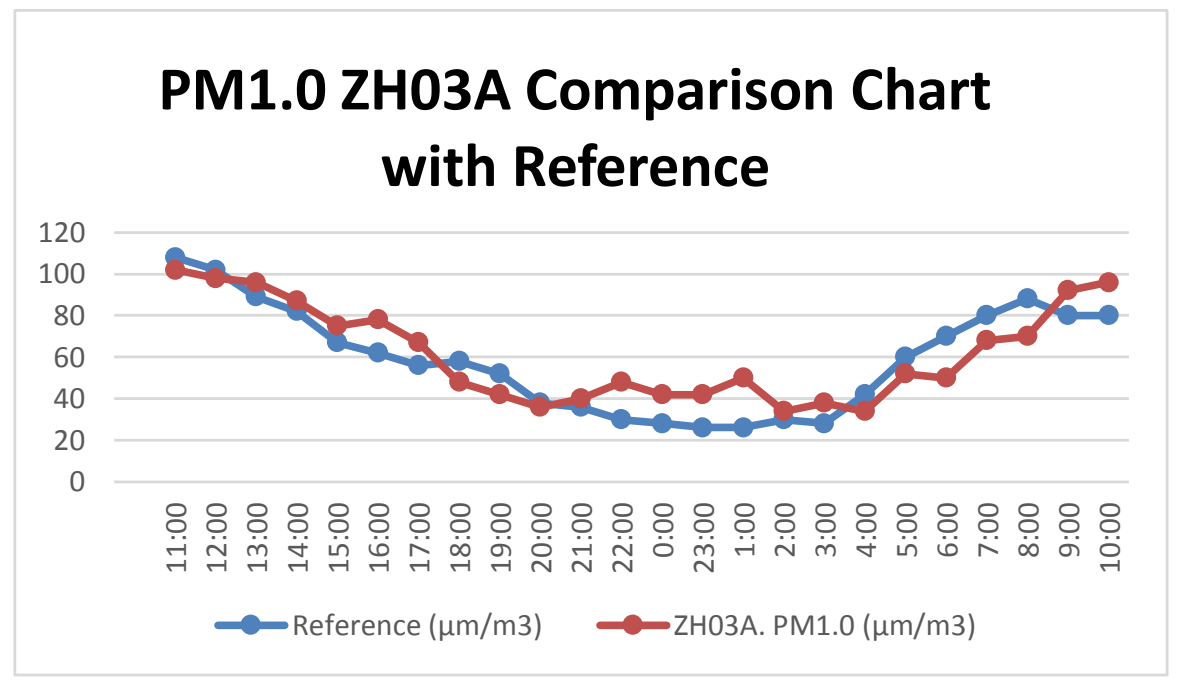

Figure 4. Comparison Graph PM1.0 ZH03A with Reference 


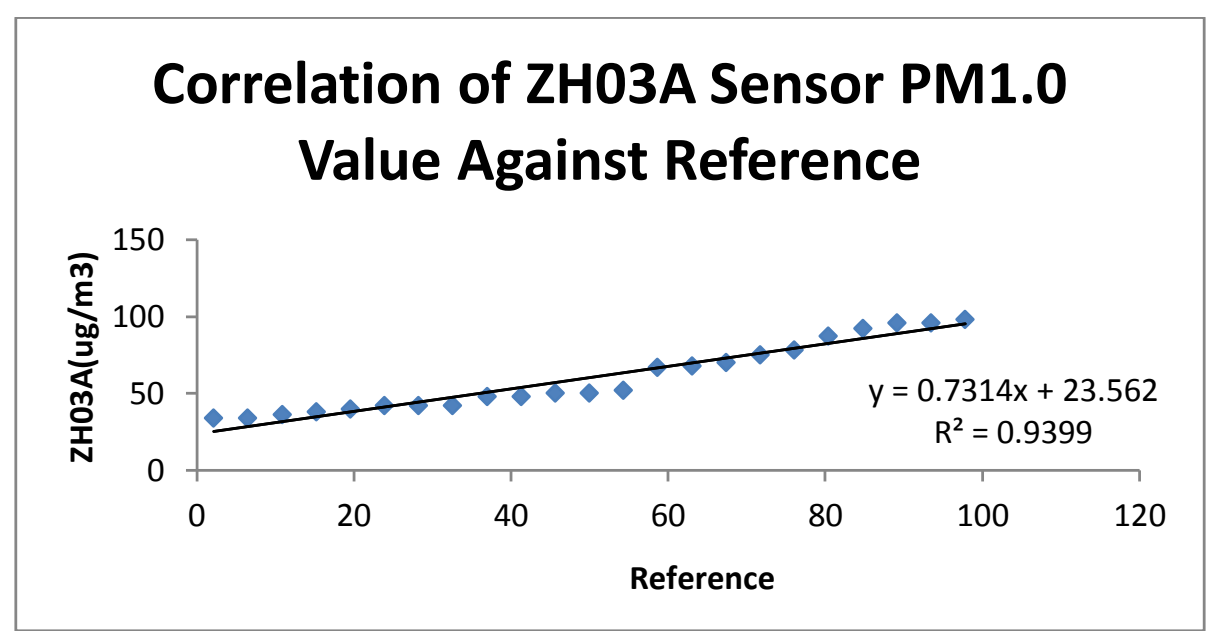

Figure 5. Graph of PM1.0 Concentration Correlation

The results calibration data of the PM2.5 and PM1.0 measurement values, the designed tool with standard tools shows that the design tool can detect the PM2.5 and PM1.0 values quite well. The value of the measurement results obtained for PM2.5 and PM1.0 read by the design tool is close to the value indicated by the calibrated operational tool, where the average correction value for PM2.5 testing is $6.5 \mu \mathrm{m} / \mathrm{m} 3$ and for PM1.0 test of $2.8 \mu \mathrm{m} / \mathrm{m} 3$, although the correction value in certain conditions is still quite far (Hatimah, et al. 2018; Dickson, 2018).

The ability of different sensors to detect particles in the air is also one of the reasons for the reading value of a slightly different tool, wherein the ZH03A sensor the smallest particle value that the sensor can read is 1 $\mu \mathrm{m}$ while in operational tools it has a better resolution of $0,1 \mu \mathrm{m}$, so that the particulate mass that can be read is different (Rieker et al., 2007; Zaatar et al., 2000). In the ZH03A sensor module, the airflow to the sensing chamber uses a small fan, while the operational equipment uses a larger fan and better suction power for air masses so that the concentration of particulates passing through the sensing chamber is greater (Pujiastuti et al., 2013; Putra, 2014). The difference in the height of the tool also affects the measurement value where the inlet height of the operational tool is higher than the design tool or the calculation of the ISPU value, using data from Table 2, namely the measurement for 24 hours starting from 11.00 to 10.00 the next day. From Table 2, it is known that the maximum value is $102 \mu \mathrm{m} / \mathrm{m} 3$, so to find the ISPU value can be determined from the equation as follows:

$$
I=\frac{\mathrm{I} a-\mathrm{Ib}}{\mathrm{Xa}-\mathrm{Xb}}(\mathrm{Xx}-\mathrm{Xb})+\mathrm{Ib}
$$

Based on data Table 2 and description of equation 2.1 it is known that $\mathrm{Xx}=102 \mu \mathrm{m} / \mathrm{m} 3 ; \mathrm{Ia}=100 ; \mathrm{Ib}=50 ; \mathrm{Xa}=$ $150 ; \mathrm{Xb}=50$ then the ISPU value can be obtained. Based on the calculation results, the ISPU value is 126 $\mu \mathrm{m} / \mathrm{m} 3$. Those in the range 51 to 150 are in the moderate category with decrease invisibility.

\section{Conclusion}

Based on the results and discussion, it can be concluded (1) it has been designed and made air quality measuring instrument which is more efficient, easy to carry, and relatively cheap price, (2) the measurement results in PM2.5 the difference in the average value between the design tool and the standard tool is 6.5 $\mu \mathrm{m} / \mathrm{m} 3$, and in PM1.0 the difference in the average value is $2.8 \mu \mathrm{m} / \mathrm{m} 3$, (3) the Air Pollution Standard Index (ISPU) value from the calculation results is $126 \mu \mathrm{m} / \mathrm{m} 3$, included in the medium category.

\section{Acknowledgments}

We are grateful to two anonymous reviewers for their valuable comments on the earlier version of this paper.

Wibawa, I. M. S., \& Putra, I. K. (2021). Design and manufacture of air quality measurements based on arduino ATmega 2560 using dust ZH03A laser sensor. International Journal of Physical Sciences and Engineering, 


\section{References}

Al-Haija, Q. A., Al Tarayrah, M., Al-Qadeeb, H., \& Al-Lwaimi, A. (2014). A tiny RSA cryptosystem based on Arduino microcontroller useful for small scale networks. Procedia Computer Science, 34, 639-646. https://doi.org/10.1016/j.procs.2014.07.091

Ansori, M. (2017), Design of Remote Particulate Meter Measurement Instrumentation Systems Using Wireless Systems and Internet Access, Lampung: Department of Physics, Faculty of Mathematics and Natural Sciences, University of Lampung.

Azhar, K. (2015). Particulate Dust Levels ( $\left.\mathrm{PM}_{2,5}\right)$ in Houses and Incidence of ARI in Toddlers in Kayuringin Jaya Village, Bekasi City, 2014, Media Litbangkes 26(1), 45-52.

Berkowicz, R., Palmgren, F., Hertel, O., \& Vignati, E. (1996). Using measurements of air pollution in streets for evaluation of urban air quality-meterological analysis and model calculations. Science of the total environment, 189, 259-265. https://doi.org/10.1016/0048-9697(96)05217-5

BMKG, 2013, Information Book on Climate Change and Air Quality in Indonesia, Jakarta: Agency for Meteorology, Climatology and Geophysics.

Budiyono, A. (2001). Impact of Air Pollution on the Environment, Dirgantara News, 2(1), 21-27.

Chandra, B. (2012). Introduction to Environmental Health, Jakarta: EGC.

Dickson, K. (2018). Pengertian Relay dan Fungsinya. Available on: https://teknikelektronika. com/pengertianrelay-fungsi-relay. $\{06 / 03 / 2019\}$.

Fahruddin. (2014). Prototype Monitoring of Water Levels in Microcontroller-Based Reservoirs, Makassar: Department of Informatics, Faculty of Science and Technology, Alauddin State Islamic University.

Falahdina, A. (2017). Environmental health risk analysis of pm2 exposure. 5 in permanent traders at the Kampung Rambutan terminal (Bachelor's thesis, UIN Syarif Hidayatullah Jakarta: Faculty of Medicine and Health Sciences, 2017).

Hatimah, H., Gunawan, A. N., \& Paramarta, I. B. A. (2018). Designing a Heart Rate and Body Temperature Measurement Tool Using Pulse Sensor and IR MLX90614 Based on ATmega328 and GSM Technology. BULETIN FISIKA, 19(2), 80-84.

Krüger, E. L., Minella, F. O., \& Rasia, F. (2011). Impact of urban geometry on outdoor thermal comfort and air quality from field measurements in Curitiba, Brazil. Building and Environment, 46(3), 621-634. https://doi.org/10.1016/j.buildenv.2010.09.006

Nazaruddin, 2018

Nazaruddin, M. (2018). $\mathrm{PM}_{2.5}$ and $\mathrm{PM}_{10}$ Digital Measurement Design, South Tangerang: MKG Instrumentation Applied Bachelor Program, College of Meteorology, Climatology and Geophysics.

Pham, C. (2014). Communication performances of IEEE 802.15. 4 wireless sensor motes for data-intensive applications: A comparison of WaspMote, Arduino MEGA, TelosB, MicaZ and iMote2 for image surveillance. Journal of Network and Computer Applications, 46, 48-59. https://doi.org/10.1016/j.jnca.2014.08.002

Pujiastuti, P., Ismail, B., \& Pranoto, P. (2013). Quality and Load of Water Pollution in Gajah Mungkur Reservoir. Ecosciences, 5 (1).

Putra, P.K. (2014). 2G Global System ForMobile Communication (GASM) Network Performance Analysis of $900 \mathrm{MHz}$ and $1800 \mathrm{MHz}$ Frequency Based on Drive Test Data at Pt. Telkomsel Padang, Padang: Department of Electronics Engineering, Faculty of Engineering, Padang State University.

Rieker, G. B., Li, H., Liu, X., Liu, J. T. C., Jeffries, J. B., Hanson, R. K., ... \& Takatani, S. (2007). Rapid measurements of temperature and $\mathrm{H} 2 \mathrm{O}$ concentration in IC engines with a spark plug-mounted diode laser sensor. Proceedings of the Combustion Institute, 31(2), 3041-3049. https://doi.org/10.1016/j.proci.2006.07.158

Zaatar, Y., Bechara, J., Khoury, A., Zaouk, D., \& Charles, J. P. (2000). Diode for process control and environmental monitoring. Applied Energy, 65(1-4), 107-113. https://doi.org/10.1016/S03062619(99)00090-2 


\section{Biography of Authors}

\begin{tabular}{|l|l||}
\hline & $\begin{array}{l}\text { I Made Satriya Wibawa was born in Baler Bale Agung, 19 May 1966. He } \\
\text { graduated bachelor's degree with Physics Degree in Physics Study Program, } \\
\text { Faculty of Mathematics, Gadjah Mada University (UGM) in 1991, in } \\
\text { Instrumentation Physics. He finished magister's degree of Physics in Physics Study } \\
\text { Program, Faculty of Mathematics, Institut Teknologi Bandung (ITB) in 1998 in } \\
\text { Semiconductor Material Physics. The research was conducted in the field of } \\
\text { Instrumentation, Sensor, and Computation. } \\
\text { Email: satriya_wibawa@unud.ac.id }\end{array}$ \\
\hline
\end{tabular}

Wibawa, I. M. S., \& Putra, I. K. (2021). Design and manufacture of air quality measurements based on arduino ATmega 2560 using dust ZH03A laser sensor. International Journal of Physical Sciences and Engineering, 5(1), 8-15. https://doi.org/10.29332/ijpse.v5n1.800 